групах за Індексом Бартел, та за модифікованою шкалою Ренкіна, помітна позитивна динаміка.

В основній групі, поєднавши методи фізичної терапії комплексно, ліквідували спастичність у м'язах по Ашворту до 2-х балів; зменшили больові відчуття, ступінь болю до 5 б.; спонукали відновленню рухової функції. I навпаки, у контрольній групі бажаних результатів за аналогічними шкалами не отримано.

Застосування методів фізичної терапії у основній групі: проводилась мануально-м'язова корекція в: аддукторах плеча та у внутрішній ротації, згиначах ліктя, пронації передпліччя, згиначах зап'ястя та згиначах пальців. Підготувавши та послабивши спастичність, поєднали з пасивними вправами на розтяг, при появі мінімально активного руху в паретичній кінцівці використали постізометричну релаксацію укріплюючи та приводячи м'язи у стан взаємодії.

Висновок. Фізична терапія пацієнтів після інсульту зі спастичністю верхньої кінцівки у пізньому періоді має надмірну актуальність для подальшого дослідження. Спастичність має негативні наслідки: скутість в м'язах, контрактури, больові відчуття, деформації кінцівок, та ін. Поєднання методів фізичної терапії, спрямовані на подальшу ліквідацію спастичних м'язів. Передбачає поетапний вплив, який сприяє відновлюванню порушених рухових функцій пацієнтів після інсульту зі спастичністю верхньої кінцівки, зменшує кількість ускладнень, підвищує рівень життя.

DOI https://doi.org/10.30525/978-9934-26-113-8-6

\title{
ВПЛИВ КОМП'ЮТЕРНОЇ ДЕНСИТОМЕТРІЇ НА ТАКТИКУ ХІРУРГІЧНОГО ЛІКУВАННЯ ФТИЗІАТРИЧНИХ ХВОРИХ
}

\author{
Маєтний Є. М. \\ кандидат медичних наук, \\ старший науковий співробітник відділення торакальної хірургії \\ Державна установа \\ «Національний інститут фтизіатрії і пульмонології \\ імені Ф. Г. Яновського Національної академії медичних наук України» \\ м. Київ, Україна
}

Туберкульоз, за оцінкою ВООЗ, визнаний глобальною небезпекою, залишається провідною причиною смерті від інфекційного агента, 
вперше перевищуючи вірус імунодефіциту людини [1,с. 18], [2, с. 317]. Хірургічне лікування сприяе підвищенню ефективності лікування, сумісно з адекватною хіміотерапією [3, с. 73] [4, с. 11]. Дискусійними залишаються питання термінів, методів та об єму хірургічного лікування [5, с. 15]. Рентгенологічні методи діагностики, зокрема компютерна томографія, залишається основним методом діагностики паренхіматозного захворювання [6, с. 69], [7, с. 87]. Важливим компонентом комп'ютерної томографії, $є$ денситометричний аналіз, кількісна оцінка щільності досліджуваних тканин і середовищ, яку виражають в умовних одиницях за шкалою Хаунсфільда (HU) [8, с. 2].

Матеріали і методи. Було проведено обстеження 353 хворих 3 верифікованим, за результатами мікробіологічного дослідження туберульозом легень, які були оперовані в хірургічній клініці НІФП. Проаналізовано клініко-рентгенологічні форми та поширеність туберкульозного ураження за рентгенологічною картиною з проведенням денситометричного аналізу уражених ділянок і вільної паренхіми легеневих полів. Вивчені види виконаних оперативних втручань та показники активності специфічного процесу за морфологічними ознаками і клінічними проявами. Проведено аналіз денситометричних показників легеневої паренхіми у пацієнтів з рецидивами специфічного запалення та при неускладненому перебігу хвороби. Дослідження проводилось у межах планових науково-дослідних робіт відділення торакальної хірургії в акредитованій клініці ДУ «Національний інститут фтизіатрії і пульмонології ім. Ф. Г. Яновського Національної академії медичних наук України» за кошти державного бюджету.

Результати i обговорення. Пацієнтам згідно клінікорентгенологічних форм захворювання проведено комп'ютерну денситометрію, а видалений резекційний матеріал був підданий ретельному патоморфологічному дослідженню. Незворотні морфологічні зміни були виявлені у всіх проперованих пацієнтів. Середні значення щільності легеневої тканини, ураженої туберкульозним процесом, у хворих із низьким, середнім та високим ступенем активності специфічного запалення згідно результатів гістологічного дослідження, в цілому, мали тенденцію до зворотно пропорційного зв'язку між щільністю та активністю запалення при всіх режимах проведення денситометричного аналізу. Застосований багатофакторний аналіз для виявлення оптимального режиму проведення комп'ютерної денситометрії у фтизіатричних хворих $з$ метою неінвазивної оцінки активності специфічного процесу у хворих на туберкульоз легень, який би міг бути єталонним при визначенні показань до хірургічного лікування зазначеного контингенту. Оцінка зв'язків денситометричних показників та гістологічних показників ступеню специфічного запалення 
при вимірюванні в режимі максимальних значень засвідчила зменшення майже вдвічі показників ординальних розрахунків. Так коефіцієнт Кендалла $-0,36$ склав $-0,36$ при асимптотичній стандартизованій помилці 0,111. Коефіцієнт кореляції Спірмена склав $-0,3913$ асимптотичню похибкою 0,139, що істотно відрізнялося від результатів, отриманих при виконанні денситометрії у режимах мінімальних значень та середніх значень показників. В цілому, аналіз кореляційних таблиць засвідчив суттєвий достовірний зворотний зв'язок між щільністю в досліджуваній ділянці легені та ступенем активності специфічного процесу в ній за гістологічними критеріями при проведенні денситометрії мінімальних значень та середніх значень щільності, але ординальні зв'язки при денситометрії в режимі середніх знгачень виявилися дещо більш значимі. Таким чином встановлено, що при середньому значенні щільності $(54,4 \pm 17,8)$ одиниць Хаунсфільда та вище, відзначається низька активність туберкульозного процесу, що відповідає фазі регресу захворювання. Значення щільності патологічно зміненої легеневої паренхіми в межах $(27,6 \pm 7,5)$ одиниць Хаунсфільда відповідають помірній активності туберкульозного процесу, характеризуючи фазу стабілізації. Середні значення щільності $(15,0 \pm 2,5)$ одиниць Хаунсфільда та нижче характеризують високу активність туберкульозного процесу і фазу прогресування захворювання.

Визначаючи тактику хірургічного лікування фтизіатричних хворих, при виявленні вогнищ 3 показниками мінімального значення щільності легеневої паренхіми (15 HU та нижче), передопераційну специфічну терапію продовжували. Хірургічний етап лікування проведений при денситометричних показниках, які відповідають стабілізації $(27,6 \pm 7,5 \mathrm{HU})$ або регресії $(54,4 \pm 37,8 \mathrm{HU})$ специфічного запального процесу, відзначався сприятливий інтра- та післяопераційний перебіг. Спостерігалося зменшення тривалості післяопераційного лікування з 14 діб до 12 діб. Відзначалася мінімінізація потреб в додаткових хірургічних маніпуляціях та додатковій медикаментозній терапії на $22,0 \%$. Проведення хірургічного лікування в сприявливих умовах призвело до скорочення терміну повної активізації хворих на 11,0% (з 12 до 10 діб) та скорочення тривалості перебування хворого в стаціонарі на $15,3 \%$ або в середньому на 7 днів.

Застосування отриманих результатів в плануванні оперативного лікування фтизіатричних хворих дозволило виявити, що на етапі завершення лікування первинного випадку ТБ у більшості пацієнтів 3 рецидивами захворювання визначалися денситометричні показники, які відповідали високій $(60,7 \%)$ або середній $(32,1 \%)$ активності специфічного процесу, що сумарно склало 92,9 \% від усього числа хворих з рецидивом ТБ. Безпосередньо при виявленні рецидиву ТБ у всіх 28 
випадках були знайдені патологічні зміни зі щільністю нижче $20 \mathrm{HU}$, що відповідає високій активності специфічного процесу.

Детальне вивчення єтапів лікування фтизіатричних хворих, які мали обтяжений інтра- та післяопераційний період, виявило відхилення значень комп'ютерної денситометрії легеневої паренхіми від умовної норми. При підвищеній (понад -730 HU) щільності паренхіми спостерігалися облітерація плевральної порожнини та міждольових щілин, фіброзні зміни кореню легені, при зниженій щільності (нижче $860 \mathrm{HU})$ - кровоточивість та недостатня герметичність шва паренхіми. 3 метою профілактики обтяженого перебігу інтра- та післяопераційногого періоду пропонуються раціональні засоби пневмолізу, розділення міждольових щілин та виконання шва легеневої паренхіми.

\section{Висновки.}

1. Порівняння данях комп'ютерної денситометрії 3 патоморфологічними характеристиками специфічного запального процесу у хворих на туберкульоз легень свідчать про високу інформативність даного неінвазивного методу встановлення активності запального процесу.

2. Використання об’єктивних критеріїв призначення хірургічного лікування, у хворих на туберкульоз легень за даними комп'ютерної денситометрії, дозволяють визначити оптимальні терміни для оперативного втручання, об єм оперативного втручання та достовірно зменшити легенево-плевральні ускладнення.

3. Вдосконалена методика хірургічного лікування, 3 використанням біологічного зварювання, дозволяє попередити локальну реактивацію специфічного запалення та знизити розвиток рецидивів захворювання.

\section{Література:}

1. Фещенко, Ю. І. Сучасні тенденції вивчення проблем туберкульозу. Укр. пульмонол. журн. 2019. № 1. С. 8-24.

2. Bloom, Barry R, et al. «Tuberculosis.» Major Infectious Diseases, edited by King K Holmes et. al., 3rd ed., The International Bank for Reconstruction and Development / The World Bank, 3 November 2017. doi:10.1596/978-14648-0524-0_ch11.

3. Фещенко, Ю. І. Хірургічний етап лікування хворих на мультирезистентний туберкульоз легень. Укр. пульмонол. журн. Додаток. 2018. № 1. С. 73-76.

4. Giller, D. B. Pneumonectomy in the treatment of tuberculosis relapse in a previously resected lung. Grekov's Bulletin of Surgery. 2020. Vol. 179, No. 2. C. 11-19.

5. The Role of Surgery in the Treatment of Pulmonary TB and Multidrugand Extensively Drug-resistant TB : WHO/Europe Consensus Paper / K. Dheda et al. 2014. URL : http://www.euro.who.int/en/health- 
topics/communicable-diseases/tuberculosis/publications/2014/the-role-ofsurgery-in-the-treatment-of-pulmonary-tb-and-multidrug-and-extensivelydrug-resistant-tb (дата звернення: 27.06.2021).

6. Lynnyk, M., Gumeniuk,M., Kalabukha, I. Informativity of computer densitometry for assessing the degree of activity of the inflammatory process in pulmonary tuberculomas. Georgian medical news. 2019. No. 296. C. 81-86.

7. Skoura E, Zumla A, Bomanji J. Imaging in tuberculosis. Int J Infect Dis. 2015;32:87-93. doi:10.1016/j.ijid.2014.12.007

8 Mascalchi M, Camiciottoli G, Diciotti S. Lung densitometry: why, how and when. J Thorac Dis. 2017;9(9):3319-3345. doi:10.21037/jtd.2017.08.17

DOI https://doi.org/10.30525/978-9934-26-113-8-7

\title{
ЕФЕКТИВНІСТЬ ТРИВАЛОЇ ТЕРАПІЇ КАНДЕСАРТАНОМ У ХВОРИХ АРТЕРІАЛЬНОЮ ГІПЕРТЕНЗІЕЮ, УСКЛАДНЕНОЮ СЕРЦЕВОЮ НЕДОСТАТНІСТЮ
}

\author{
Мирний С. П. \\ кандидат медичних наук, дочент, \\ доиент кафедри медицини катастроф, \\ військової медиинни та нейрохірургї \\ Запорізький державний медичний університет
}

Мирна А. I.

кандидат медичних наук, доиент, доцент кафедри фізичної терапії та ерготерапії Національний університет «Запорізька політехніка»

\section{Мирний Д. П.}

кандидат медичних наук, дочент,

доцент кафедри терапї, клінічної фармакологї та ендокринології

Державний заклад «Запорізька медична академія післядипломної освіти Міністерства охорони здоров `я Украӥни»

м. Запоріжжя, Украӥна

Мета - вивчити вплив фармакотерапії кандесартаном на внутрішньосерцеву гемодинаміку, рівень артеріального тиску (АТ) та показники вуглеводного обміну у хворих на артеріальну гіпертензію (АГ), ускладнену хронічною серцевою недостатністю $(\mathrm{XCH})$. 